\title{
AGRICULTURAL BIOTECHNOLOGY AND THE “EARLY-WORKING" EXEMPTIONS UNDER THE PATENT ACT
}

\author{
MARTIN PHILLIPSON
}

The author explores the availability to generic manufacturers of wo rescarch exemptions under the Canadian Patent Act In order to expedise later market eniry: processes of research and development and federal product approval are often initiated prior wo patent expiry. The question arises of when these "early-working" endean ours will violate the protection offered by a patent. The "research exemption" has been interpreted narrowly, and may only be of limited use so potential manufaciurers engaging in carly. development of protected prochucts. However. the "regulatony approval exemption" has becn given a wider interpretation, both in Canada and the United States. and it is likely that processes related io regulatory approval will not as readily be considered as paten infringing. Finally: the atuhor also bric/y. explores commercial and strategic considerations as they relate to these legal issues.
L'auteur explore la possibilité d'miliser deux cuemptions de recherche pour les fabricams génitiques en ver/u de la Loi sur les brevets dit Comale. Afin daccilerer lex entries tardives stur te

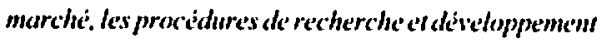
et fapprobation dis produit par le gouternement feidiral somt souremt mises on marche arom lexpiration du brevet. Il faudrait se demander à quel momen ces dimarches de "mise au point a lavance" violent-elles la protection assurée par le brevet. I." "exemption de recherche "a été imerprétie rigotureusement. et les fabricants eventuels intéressés $\dot{a}$ developper. de maniere pricoce, les produits protigis ne peweon en faire qu iun usage limite. Cependant. I" exemprion dapprobation riglementuire o a ifé plus largement interprétie. an Canada comme aux Elats-Unis, et il semble que les processus relatifs à Tapprobation réglementaire ne soien pas de sitot considerés comme ètant une infraction au brevet. Enfin. I'auteur survole les implications commerciales ef stratégiques relatives $\dot{a}$ ces questions juridiques.

\section{TABLE OF CONTENTS}

I. INTRODUCTION ................................ 765

II. THE UTILITY OF THE "EARLY WORKING" EXEMPTIONS . . . . . . 766

III. THE EXPERIMENTAL USE OR "JUDICIAL"

RESEARCH EXEMPTION ......................... 767

IV. THE "REGULATORY APPROVAL" EXEMP'TION $\ldots \ldots \ldots \ldots \ldots \ldots \ldots 770$

V. THE SCOPE OF THE "REGULATORY APPROVAL."

EXEMPTION ................................... 773

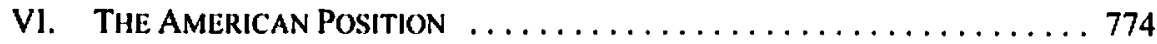

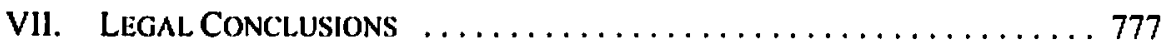

VIII. EXTRA-LEGAL ISSUES: COMMERCIAL AND

Strategic Considerations $\ldots \ldots \ldots \ldots \ldots \ldots \ldots \ldots \ldots \ldots \ldots 77$

IX. Conclusion ................................ 778

\section{INTRODUCTION}

The use of biotechnology in agricultural production is now widespread in Canada. Canola growers in particular have enthusiastically embraced herbicide tolerant (HT) varieties, most

Associate Professor, College of Law, University of Saskatchewan. The author wishes to thank Stuart Smyth, Stephen J. Ferance, and Barbara Von Tigerstrom for their assistance in gathering materials and Lynda J. Lee for her editorial assistance. The author would also like to thank the three anonymous expert reviewers for their insightful comments. All errors remain the fault of the author. 
notably Monsanto's Roundup Ready ${ }^{\mathrm{TM}}$ product, which uses a genetically modified gene resistant to the effects of the herbicide glyphosatc. As MacKay J. explained in Monsamo Canada Inc. v. Schmeiser:

Glyphosate herbicides such as Roundup have been widely used in Canada for many years. Canola tolerant (o glyphosale first became available commercially in Canada in 1996. It has been marketed under licensing arrangements through Monsanto Canada under Monsanto's trade-mark Roundup Ready Canola. In 1996 approximalcly 600 farmers in Canada planted Roundup Ready canola, on some 50,000 acres. By 2000. approximately 4.5 to 5 million acres of Roundup Ready canola were planted in Canada, by about 20,000 farmers, producing nearly $40 \%$ of canola grown in Canada.'

Monsanto was issued a Canadian patent on this gene in $1993,{ }^{2}$ and the product was first offered for sale in 1996. To grow Roundup Ready TM Canola, farmers must enter into a contract with Monsanto to purchase Monsanto seed and herbicide from approved dealers on an ammal basis and pay an annual Technology User Fee of $\$ 15$ per acre. Given the popularity of the product, Monsanto is carning significant revenue from Roundup Ready ${ }^{\mathrm{TM}}$ Canola in Canada. The lenglhy litigation between Monsanto and Saskatchewan farmer Percy Sclumeiser ${ }^{3}$ is clear evidence of the importance to Monsanto of maintaining the validity (and commercial integrity) of this particular product and its associated patent.

The ' 830 Patent is due to expire in 2010. Given its aforementioned commercial success, it would appear highly attractive to competitors, university researchers, and/or farming groups to attempt to produce generic versions of this product. Assuming the figures cited by Mackay J. are correct, at a minimum Monsanto carns $\$ 67.5$ million per annum from Technology User Fees in Canada. This figure is, of course, in addition to the sales revenue generated by the seeds and herbicides. Farm revenues could be significantly enhanced if a generic version of glyphosate-resistant canola could be marketed without the additional technology user fee.

The aim of this article is to explore whether potential producers of generic glyphosateresistant canola can avail themselves of exemptions that exist under the Patent $A c t^{5}$ (and associated jurisprudence) to ensure a timely entrance onto the Canadian market in 2010.

\section{I. THE UTILITY OF THE "EARLY WORKING" EXPMP'IONS}

In Canada, plants that have been modified via genetic engineering are classified by federal regulators as Plants with Novel Traits (PNTs). Their commercial release must be approved by the Canadian Food Inspection Agency (CFIA), Health Canada, and Environment Canada.

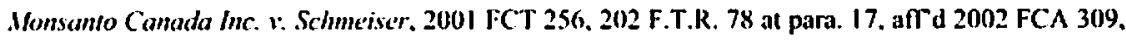
[2003] 2 F.C. 165. rev d 2004 SCC 34, [2004] I S.C.R. 902 [.1fousamo].

"Gilyphosale-Resistant Plants," Can. Paltent No. 1313830 (6 August 1986, issued 23 February 1993) [.830 Patent].

Sec supra note I. Much commentary also exists on this litigation. See, e.g., Martin Phillipson. "Giving A way the Farm?" The Rights and Obligations of Biotechnology Multinationals: Canadian Developments" (2005) 16 K.C.L.J 362 and Bruce Zifl, "Travels Witl My Plant: Monsomso v. Schmeiser Revisited" (2005) 2 U. Ottawa L. \& Tech. J. 493.

Monsanto (T.D.), supra note I.

R.S.C. 1985 , c. P-4. 
Each of these federal agencies has its own set of approval procedures." Canada adopts a unique approach to the regulation of such crops, regulating them according to their "novelty" rather than the process by which they were produced. ${ }^{7}$ This unique system is seen by many as time consuming:

While regulations pertaining to plants with novel traits are increasingly frustrating crop varicty researchers. the various federal departments and agencies involved in the regulatory process have given uo indication that change is to be expected. Under the present system, a minimum of two years should be expected for the risk assessment process, but the reality is that it may take comsiderably longer. ${ }^{x}$

Given this situation, any potential market entrant wishing to capitalize on the expiration of Monsanto's '830 Patent in 2010 should begin research in earnest. However, any such research might risk infringing upon that patent ${ }^{9}$ unless it can garner the protection of either of the two "early-working" exemptions that exist under s. 55 of the Patent Act" and associated jurisprudence.

\section{THE EXPERIMENTAl, USE OR "JUDICIAL." RESEARCH EXEMPTION"}

The law regarding the scope and extent of any potential research exemption under the Patent $A C l$ is viewed as being in a highly unsatisfactory state: "[The] lack of a clear research

A critique of these regulatory processes is beyond the scope and purpose of this article. For a detailed outline of the process, see Royal Society of Canada. Report to Health Canada. Canadian l'ood Inspection Agency, and Environment (annadia, "Elements of Precaution: Recommendations for the Regulation of Food Biolechnology in Canada" (January 2001), online: Royal Socicty of Canada <www.rsc.ca//files/publications/exper__panels/foodbiotechnology/GiMreportiN.pdf >. For analysis of the system and proposals for reform. ste Canadian Biotechnology Advisory (ommitlee (CBAC), Report to the Government of Canada Biotechnology Ministerial Coordinating Commitlec. "Improving the Regulation of Genetically Modified Foods and Other Novel Foods in Canada" (August 2002), online: CBAC <http://cbac-cech.ca/epic/interne//incbac-cech.nsf/vwapj//mproving_Regulation_GMFrodAug 02.pdf $\$$. For a very recent analysis of the challenges facing this regulatory system. see David Cassle ef al., "Convergence in Bioteclmology lunovaltimn: Cases Studies and lmplieations for Regulation" (February 2006). online: University of Toronto <www.utoronlo.ca/jeb/genomics/decuments/ Convergent_Bistechuology.pdt--

3 So non-genetically enginetered plants (suchl as those created via mutagenesis) and plants with no history of development and use in Canada are also regarded as PNTs.

* Stuart Sinyth, "Implications and Polential Impacts from the Expiry of Palents on Herbicide Tolerant Canola Varieties" (July 2006), online: Saskatehewan Canola Development Commission <www.sask canola.com/pdfs/sede-patent-report.pdl> at 39.

Supra note 5, 5. 42, which grants the palentee the exclusive right to usc. sell, construct, or manufacture the patented product for the lifetime of the patent. As the 830 Piltent application was liled before 1 October 198\%. s. $45(1)$ ol the Act establishes a monopoly peried of 17 years.

For an exhaustive, and highly impressise, analysis of this exemption and the "regulatory approwal" exemption, see Stephen J. Ferance. "The Experimental Use Delience to Patent Infriugement" (2013) 20 C.I.P.R. I. For an excellent analysis of these exemptions in the context of academic research at Canadian universities, see B.M. Robinson. "Pin-Stripes, Test Tubes and Patents: Is the Conmercialization of University Research Consistent with the Fundamental Tenets of the Patent Act?" U. Otlawa l.. \& Tech. J. [forthcoming in 2006]. 
exemption [has] detracted from basic research.... The ... Patent Act must therefore be amended to include a specific research exemption that clearly outlines the boundaries."12

In 2004, the Canadian Biotechnology Advisory Committee (CBAC) issued an Advisory Memorandum to the Government of Canada, recommending that a specific research exemption be included in the Patem Acl containing the following statements:

It is not an infringement of a patcent fo use a patented process on product cither:

(a) privately and for mon-commercial purposes, or

(b) to study the subject-muster of the patented invention to investigute' its propertics, improve upon it. or create a new product or process. ${ }^{13}$

This recommendation was based upon the CBAC's earlier finding in its 2002 report on the patenting of higher life forms ${ }^{\text {it }}$ that the "judicial" research exemption in Canada was "vague." The source of this exemption was a 1971 decision of the Supreme Court of Canada. In Micro Chemicals Lid. v. Smith Kline \& French Inter-American Corp. ${ }^{15}$ the Court was asked to examine whether a corporation, which applied for a compulsory licence to manufacture a patented pharmaceutical product, was an infringer. In support of its application the defendant (Micro Chemicals) had prepared a small batch of the drug to be able to prove that it could manufacture the product to the requisite commercial and industry standard. Justice Hall held that an experimental user without a licence, in the course of bona fide experiments with a patented article, was not at law an infringer:

The use Miero was making of the patented substance here was not for profit but to establish the fact that it could manufacture a quality producl in accordance with the specifications disclosed in respondent's application for Palent No. 6122(144. Walsh J. found that Micro's experiments prior to January 22. 1966. constituted a technical infringement as they were not carried out for the purpose of improving the process but to enable Micro (o) produce it commereially as soon as the licence it had applied for could be obtained. I cannot see that this sort of experimentation and preparation is an infringement. It appears to me to be the logical result of the right to apply for a compulsory licence. ${ }^{16}$

$12 \quad$ See Ikechi Mgbeoji \& Bryon Allen. "Patent First, Litigate Later! The Scramble for Speculative and Overly Broad Genetic Patents: Implications for Access to Health Care and Biomedical Research" (2003) 2 C.J.L.T. 83 at 92. CBAC. Advisory Memorandum. "Rationalizing Patent Law in the Age of Biotechnology" (September 2004), online: (BAC <http://cbac-eceb.ca/epic/interne/incbac-cecb.ns//wapj/Rationalizing_ Patent_Law_Final_E.pdi> at 4. epic/sile/cbac-cccb.nsf/vwapj/E980_IC_IntelProp_e.pdI/ \$FIL.E/E980_IC_IntelProp_c.pdPS. 
While Micro Chemicals has often been regarded as authority for the existence of a judicial research exemption under the Patent $A c t,{ }^{17}$ the decision is now over 30 years old, and the compulsory licensing provisions addressed therein have since been repealed. These factors certainly bring the contemporary value of the decision into question, and it should not be regarded as authority for the existence of a broad-based research exemption. As Ferance states: "There is ... an element of uncertainty as to whether a court may find that Micro Chemicals no longer applies under the present Patent Act and that there is no longer any basis in law to sustain an experimental use defence beyond the narrower defence for improvement purposes enunciated by ... Walsh J. at trial in Micro (hemicals."18

This uncertainty regarding the scope of the experimental use exemption persists in spite of s. 55.2(6) of the Patem Act, which states:

For greater certainty, subsection (1) does not affect any exception to the exclusive property or privilege granted by a patent that exists at law in respect of acts done privately and on a non-commercial scale or for a non-commercial purpose or in respect of any use, manufacture, consisuclion or sale of the palented invention solely for the purpose of experiments that relate to the subject-matter of the patent. ${ }^{19}$

However, the CBAC notes: "While section 55.2(6) explicitly prescrves the common law exception as identified in the Supreme Court of Canada decision, it does nothing to clarify either its nature or extent."20

A recent decision, however, may have removed some of this uncertainty and appears to confirm Ferance's position. In Merck \& Co. v. Apotex Inc., ${ }^{21}$ Hughes J. clearly envisaged the exemption in its narrower, improvement-oriented form:

The Supreme Court of Canada in [Micro Chemicals] dealt with whether ecrtain exemptions existed al common law respecting patent infringement. It found that some exemptions exist ... [and] affirmed a decision of the English Court of Appeal in Frearson v. Loe (1878), 9 Ch. D.48 which states that there is a doctrine of "fair dealing" in respect of patent infringement:

Patent rights were never granted to prevem persons of ingenuity exercising their talents in a fair way: But if there be neither using nor vending of the intention for profit. the mere muking for the purpose of experime'nt. and not for a frandulem purpose. ought not io be considered within the prohibition and. if it were, it is cerlainly not the subject for an injunction.

[T] he partics acknowledged that should the Coun find for the plaintiff on the infringement issuc. damages were not warranted and were not being claimed. This follows. of course, from the fact that the Cosem device is still in the experimental or research stage of its ultimate developmenl.... Until Cosem, at some stage of its product development, should decide wo give a fix lo a particular model and take steps to manufacture, promole and sell it, its current use of a paired, bipolar and sequential mode of stimulation does not constitute an infringement of the palent-in-suit. 
The Supreme Cuurt ... found that an experimental user, without a license, in the course of bona fide experiments with a patented article was not an infringement. The use of the product, not for protit, but to establish the lact that a person could manulacture a product in accordunce with the patent, was not an infringement.

In this case, the evidence shows that there has been a use of lisinopril that should be considered in the circumstance of "lair dealing". That is the use of lisinopril in ongoing rescarch and development of alternate lormulac, alternale technicues for tablet making and the like.

As to this rescurcly and development material, I find that it clearly lalls within the "fair dealing" excmption provided by the Supreme Court of Canada in Mficro Chemicals. ${ }^{22}$

In the context of producing a generic version of HT canola, potential developers would not necessarily be sceking to improve the subject matter of the ' 830 Patent, but would rather probably be simply engaged in replicating it. This could well render such work beyond the scope of bona fide experimentation. As such, it appears that the experimental use defence as outlined in Micro Chemicals (and restated in Merck) offers little protection from potential infringement litigation in this context.

\section{THE "REgUL,ATORY APPROVAL." EXEMPTION}

There is clear statutory authority for the existence of a "regulatory approval" exemption. Section 55.2(1) of the Patent Act states:

It is trot an inlringement of a patent for any person to make, construct, use or sell the patented invention solely for uses reasomably related to the developinent and subinission of information required under any law of Canada, a province or a country other than Canada that regulales the manufacture, construction. use or sale of any prodict. ${ }^{23}$

Despite this provision, the $\mathrm{CBAC}$ asserted that such language was insufficient: "[The] situation [regarding research exemptions] was not remedied through the introduction of section 55.2 into the Pafent Act. That section sets out a specific experimental use exception applicable only to regulated inventions such as pharmaceuticals."24

It is submitted, however, that this criticism of the limited scope of s. 55.2(1) is simply an aspect of the CBAC"s wider dissatisfaction. In its opinion, what is required is a broad-based research exemption providing a statutory safe-haven for researchers to engage in basic or fundamental research in fields where patents are prevalent. Indeed, their criticism of s. 55.2(1) acknowledged that the exemption only covered "regulated inventions such as pharmaceuticals."2s Further support for an overtly pharmaceutical focus for s. 55.2(1) comes from the Supreme Court of Canada decision in Bristol-Myers Squibb Co. v. Canada (A.G.). ${ }^{26}$

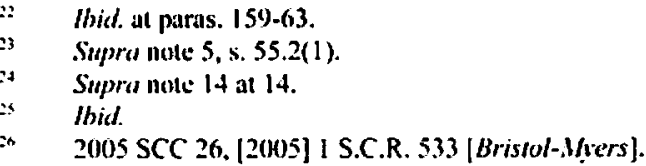


The case is also useful in articulating the rationale underlying the "regulatory approval" cxemption.

In Bristol-Myers, the Supreme Court was asked to rule in a dispute between a major pharmaceutical company and the federal government, which in 2001 had issued a Notice of Compliance (NOC) to a generic pharmaceutical manufacturer for a product similar to that of the respondents' (Bristol-Myers) patented anti-cancer drug Taxol." Bristol-Myers sought to have the NOC quashed. All disputes pertaining to the issuance of a NOC are to be determined in accordance with the Patented Medicines (Notice of Compliance) Regulations. ${ }^{\mathrm{*}}$ In writing the majority decision, Binnie J. discussed the nature of the statutory exemption in s. 55.2 and the circumstances surrounding its introduction: "In a reversal of policy, Parliament in 1993 repealed the compulsory licence provisions of the Patem Act by what became known as Bill C-91 (S.C. 1993, c.2) and extinguished all compulsory licences issued on or after December 20, 1991."3"

However, to offset the potential anti-competitive effects of the repeal of the compulsory licensing provisions, Binnie J. notes that.

having agreed to respect the 20-year monopoly granted by patents. Parliament wished to facilitate the entry of competition immediately thereafter. It acted to climinate the usual regulatory lag of two yeirs or more after expiry of a patent for the generic manufacturer to do the work necessary to obtain a NOC. Parliament did so by introducing an cxemption from the owner's patent rights under which the generic manufacturers could work the patented invention within the 20-year period ("the carly working exception") to the extent necessary to obtain a NOC at the time the patent(s) expired (s. $55.2(1)$ )... In order to present abuse ol the "early working"... [exception] to patent prolection, the govemment enacted the NOC Regulations that are at issue in this appeal. 311

While both the CBAC and the Supreme Court discuss s. 55.2(1) in the context of pharmaceuticals, the language of the Court confirms that the section creates an "early working" exception for potential producers of a generic version of a patented invention. However, the language of the section is clear in that it only provides for rescarch to the extent necessary to facilitate an application for the requisite regulatory approval (in this case the NOC). In fact, the language used in s. 55.2 closely mirrors the so-called "regulatory review" exemption in U.S. law, which is known as the "Bolar exemption." 31

In order for a pharmaceulical product to be marketed in (anada. a Notice of Compliance (NOC) must be issued. The NOC certilies that the manufacturer's product has satisticd quality, saliely, and efficacy regulations passed under the auspices of the Food amd Dortgs ACt. R.S.C. 1985. c. F-27. S.O.R./93-133. The Regulutions were last amended on 5 October 2006 by the Regulutions amending the l'atented Medicines Norice of (ompliance) Regulanions. S.O.R./2006-242.

Supro nole 26 at para. 10.

thidl at para. 11.

Sec 35 U.S.C. \$27l(c). The statute was passed to reverse a Federal Court decision of Rorkte Products Inc. v. Bolar Pharmacewical Co.. Inc., 733 F.2d 858 (Fed. (ir. 1984) [Roche Prothe Is Inc. I. The Court ruled that infringing conduct for the purpose of making submissions for regulatory approval was not excused by the "scientific use" exemption in U.S. patent law, and could thus be prohibited by the patent holder. However, in the United Stales the Bolar exemption is restricted to the pharmaceutical sector. 
In Procter \& Gamble Pharmacenticals Canada, Inc. v. Canada (Minister of Health), Rothstein J.A. stated:

Subsection 55.2(1) states that it is not an infringement of a patent for a person to take steps for the development and submission of information required for a notice of compliance from the Minister of Health. If the generic restricts its activities to the development and submission of such information, it will not infringe a patent. However, paragraph $55.2(4)$ (e) authorizes regulations to prohibit infringement of the patent if the generic oversteps what it is authorized to do under subsection 55.2(1). Issuance of a notice of compliance that would allow a generic to makc, construct. use, or sell a patented invention in competition with a patentee during the lifetime of a valid patent is precisely what the Regulations are designed to prevent. $^{32}$

However, the courts have not explicitly stated whether s. 55.2(1) could apply to generic manufacturers in other fields where regulatory approval is required prior to marketing, such as agricultural biotechnology. Ferance is adamant that it would apply: "[I]t is clear from the references to 'a patented invention' and 'any product' that this exception is not limited to any particular type of product." ${ }^{33}$

Indeed, the language of the Patent Acr makes no specific reference to pharmaceuticals, but of the 128 cases that have referred to $s$. 55.2 since it became law, 18 have referred to $s$. $55.2(1)$. Of these 18 cases, however, 17 have been in the context of pharmaceutical products and NOCs.

The one exception is Visx Inc. 1. Nidek Co. in which Wetston J. noted that "[s]ection 55.2(1) applies to pharmaceutical patents and does not apply to a medical apparatus."34 Justice Wetston also stated that he based his conclusion on the analysis of MacKay J. in Apotex Inc. v. Cancada (A.G.). ${ }^{35}$ The decision of Wetston J. was reversed on appeal, with Strayer J.A. ruling that Apotex "involved a pharmaceutical patent and it did not purport to determine the scope of subsection 55.2(1) upon which the defendant relies here. The scope to be given subsection 55.2(1) remains in our view an arguable issue and, as applied here, potentially one of mixed law and fact." ${ }^{36}$

It is submitted that in Apotex, MacKay J. was referring to specific regulations passed pursuant to s. 55.2(4) of the Patent $A C t$ that were limited to pharmaceutical products, and not the more general language of s. 55.2(1). Apotex is one of Canada's leading generic drug manufacturers. In its submission to the Court they argued that "the words of section 55.2 are said to be clear that Parliament intended the regulation of patents in general, not limiting that section to pharmaceutical patents. ${ }^{37}$ 
Justice MacKay stated that he was "prepared to accept that interpretation, but [he did] not agree with all of the implications Apotex draws from this."

It is submitted that the language of s. 55.2(1) clearly encompasses the notion of a "regulatory approval" exemption extending beyond the pharmaceutical industry.

\section{THE SCOPE OF THE "REGULATORY APPROVAL" EXEMPTION}

While judicial confirmation of the broad scope of the s. 55.2(1) exemption has not been forthcoming, public clarifications by the federal government have, in fact. been more forthcoming. In Canada - Patent Protection of Pharmaceurical Prodicts, ${ }^{39}$ the World Trade Organization's Dispute Settlement Body (WTO DSB) received a complaint from the European Community that, inter alia, s. 55.2 of the Patent Act breached Canada's obligations under various provisions of the TRIPs Agreement: ${ }^{40}$

[T]he provisions of s. 55.2(1) conceming activities related to the development and submission of in formation required to obtain marketing approval for pharmaceutical products carried out without the consent of the patent holder violated the provisions of Article 28.1 of the TRIPs Agreement.

Canada, by treating palent holders in the ficld of pharmaceutical inventions by virtue of these provisions less favourably than inventions in all other fields of technology, violated its obligations under Article 27.1 of the TRIPs Agreement requiring patents to be available and patent rights enjoyable without discrimination as to the field of technology. ${ }^{41}$

In essence, the European Community alleged that in spite of the broad wording of the "regulatory approval" exemption in s. 55.2(1), it only applied de fac/o to the pharmaceutical industry, and such discriminatory legislation breached Canada's non-discrimination obligations under the TRIPs Agreement.

The Panel found in Canada's favour and could find no support for the European Community's contention that s. 55.2(1) applied solely to the pharmaceutical industry. Of particular significance were Canada's own statements as to the scope of the "regulatory approval" exemption:

The Pancl concluded that the European Communities had not presented sufficient evidenec to raise the issue in the face of Canada's formal declaration that the exception of Section 55.2(I) was not limited to pharmacewical products. Absent other evidence, the words of the stutute compelled the Panel to accept Canuda's assurance that the exception was legally available to every product that was swbject to marketing approval requirements. In reaching this conclusion, the Panel took note that its legal finding of conformity

World Trade Organization (WTO), Report of the Panel on Canado - Pafen Protection of Pharmaceutical Prodicts, WTO Doc. WT/DSI14/R (2000), online: WTO <www.wto.org/english/ tratop_e/dispu_e/7428d.pdP.

40

WTO, Agrecment on Trade-Related Aspects of Intellechual Property Rights. Annex IC of the Marrakesh Declaration Agreement Establishing the World Trade Organization (15 April 1994). 33 I.L.M. 1197 [TRIPS Agreement]. 
on this point was based on a finding as to the meaning of the Canadian law that was in turn based on Canada's representations as to the meaning of that law. ${ }^{42}$

Given these public statements by the Government of Canada as to the scope of the "regulatory approval" exemption, it is clearly envisaged that such an extension extends beyond the pharmaceutical context. Indeed, the WTO DSB Panel noted that, "[a]pplied literally, these words apply to any of a wide range of products that require regulatory approval for marketing. The EC itself mentioned agricultural chemicals, foodstuffs, cosmetics, automobiles, vessels and aircraft as products that often require regulatory approval. $" 43$

Furthermore, the WTO DSB Panel noted that, "Canada denied that the de jure scope of Section $55.2(1)$ is limited to pharmaceuticals ... and has reaffirmed without qualification that the legal scope of the statute is as broad as the words indicate."

While the availability and potential scope of the so-called "judicial" research exemption is questionable (given subsequent legislative amendments), ${ }^{\text {t5 }}$ producers of generic versions of non-pharmaceutical patented products requiring regulatory approval may well be able to engage in work related to that approvals process prior to the expiry of any patent. However, as Ferance notes: "The recent WTO Report ... may provide guidance, although [it] must be treated with caution, because it lacks the precedential status of Canadian jurisprudence."

Given the absence of Canadian judicial authority defining the scope of the "regulatory approval" exemption, it may be of use to examine American jurisprudence on the Bolar exemption that uses language virtually identical to that of s. 55.2(1) of the Patent Act. ${ }^{77}$

\section{The American Position}

As stated above, the language used in s. 55.2(1) of the Patent Ach ${ }^{8}$ is modeled on that of the so-called Bolar exemption. Therefore, any American case law defining or clarifying the scope of that exemption may be of some value.

In 2005, the United States Supreme Court in Merck KGaA v. Imegra Lifesciences I, Lid. ${ }^{49}$ unanimously held that the text of the Bolar exemption provides a "wide-berth" for the use of patented drugs in relation to federal regulatory processes, including pre-clinical studies. The decision is being viewed by many as a significant restriction on the rights of patent holders in the United States. ${ }^{50}$

lbid. at 172 [emphasis added].

lbid. at 171 .

lbid. at 172 (including $n .434$ ).

Sec. e.g. Ferance, suppra note II.

lbid. at 3 [footnote omitted].

See Roche Products Inc., supra nute 31.

Supra note 5.

545 U.S. 193 (2005) [Imtegra Lifescience].

Sec, e.g., Janice Mueller, Supreme Couri Decision Curbs Rights Of Patem Holders (13 June 2005). online: IP Law Bulletin <www.iplawbulletin.com>. 
With regard to the "judicial" experimental use exemption, American law appears much less favourable. In Madey v. Duke University, ${ }^{51}$ the Federal Court of Appeals was asked to examine the common-law or "judicial" research exemption in the United States. The origins of this exemption in the United States lie in the 1813 decision of Story J. in Whittemore $v$. Cutter, who stated: "[I]t could never have been the intention of the legislature to punish a man, who constructed such a machine merely for philosophical experiments, or for the purpose of ascertaining the sufficiency of the machine to produce its described effects."\$2

In a highly controversial decision, the Court in Madey held that this exemption in United States patent law should be interpreted very narrowly. They concluded:

In short, regardless of whether a particular institution or entity is engaged in an endeavor for commercial gain, so long as the act is in furtherance of the alleged infringer's legitimate business and is not solely for amusement, 10 saltisfy idle curiosity, or for strielly philosophical itzuiry, the act does not qualify for the very narrow and strictly limited experimental use defense. Moreover, the profit or non-profit status of the user is not determinalive. ${ }^{33}$

Apart from its dramatic reduction of the scope of the exemption, Madey is also of interest for present purposes as it involved research conducted at a university. The ultimate conclusion to be drawn from the decision is that there may no longer be any such thing as "pure research" in the university context. As universities increasingly form research partnerships with commercial third parties, it is less possible to characterize such research as "non-commercial." Previously, it had been thought that if research was conducted at a publicly funded institution, the mere fact of that status might garner the protection of the exemption. The decision in Madey firmly disavows such a belief. As Jennifer Miller notes: "[l]t is clear that, under the [new test in Madev], universities and non-profit organizations now face numerous additional obstacles to their performance of basic research, and it is this result and the fear that such a result will inevitably stifle the progress of science that has incited much outcry from the scientific community.".:4

While the restrictive approach of the Court in Madey is noteworthy in its own right, it is also significant if, as suggested above, university rescarchers or farming groups in Canada attempt to avail themselves of the "judicial" research exemption. As the available Canadian jurisprudence lacks clarity ${ }^{55}$ and is in need of legislative refinement, "st an analogous American decision may be highly persuasive in the absence of intervening clarification by a Canadian authority.

307 F.3d 1351 (Fed. Cir. 2001) [Madey].

29 F. Cas. 1120 (C.C.D. Mass. 1813 ) at 1121.

Supra note 51 at 1362.

Sec Jennifer Miller, "Sealing the Coffin on the Experimental Use Exception," online: Duke L. \& Tech.

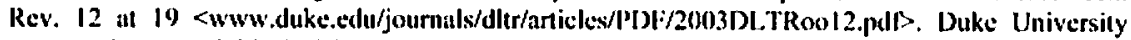
attempled to appeal this decision to the Supreme Court of the Uniled Stales, but leave was denied. For a Canadian perspective on intellectual property law and the clanging nature of University research, sec Robinson, supra note 11 .

$3 \quad$ See Mgbeoji \& Allen, supra nole 12.

so See supra note 14. 
The probative value of American intellectual property jurisprudence in Canadian courts is the subject of perennial (if not interminable) debate. Writing for the majority of the Federal Court of Appeal in the infamous Harvard Mouse case, Rothstein J.A. noted:

[W] hile United States patent decisions are obviously not binding on Canadian courts, where the statutory language which is being interpreted is similar in both countries and where the reasoning underlying the United States Court's interpretation of the language is persuasive, there is no reason why Canadian courts should ignore the U.S. jurisprudence... I am, therefore, of the view that the majority opinion of the United States Supreme Court in Chakrabarby provides useful guidance in interpreting the definition of "invention" in the Canadian Patent ACt, and ... I have placed significant reliance on it. ${ }^{57}$

However, when faced with the same language in the same decision, Isaac J. commented in dissent: "I conclude then that our decision on this appeal should not be affected in any way by the fact that the oncomouse has been patented in the United States of America." 58

For present purposes it is neither necessary, nor advisable, to adjudicate such disputes. However, it is undeniable that American decisions in the biotechnology field have often influenced the development of Canadian patent law and policy. ${ }^{59}$

Given that influence, it is arguable that notice should be taken of the decisions in Integra Lifesciences and Madey. Certain commentators ${ }^{60}$ assert that Integra Lifesciences represents a step back from the overly restrictive approach adopted in Madey (at least in the pharmaceutical context) in that: "In this regard, the statutory exception is a revitalization of research protection for drug manufacturers who lost the common law exception in Madey." ${ }^{\text {th }}$

What the American jurisprudence may provide, therefore, is judicial confirmation that the "regulatory approval" exemption provides a safer haven for potential generics researchers than the "judicial" research exemption.

37 Presiden and Fellon's of Harvard College v. Canada (Commissioner of Patems), [2000] 4 F.C. 528 at paras. 140, 147 (C.A.) [Harvard Mouse]. The Supreme Court of Canada ultimately reversed Rothstein J.'s decision. See (2002), 2 I C.P.R. (4th) 417. However, it is submitted that the discussion cited here is still valid evidence of a continuing debale as to the utility of American jurisprudence in Canadian biotechnology law.

Ibid. at para. 74. For a "classic" discussion of the value of American jurisprudence in Canadian Intellectual Property cases, see Harold G. Fox. The Canadian Law and Practice Relating to Letfers Palent for Imention, 4th ed. (Toronto: Carswell, 1969).

As discussed in /Jancard Mouse, ibid, the landmark United States Supreme Court decision in Diamond. Commissioner of Patemts and Trudemarks v. Chakrabarty, 447 U.S. 303 (1980) |Diamond| is onc such case. Diamond opened the door to life patenting in the United States and its reasoning was subsequently ciled with approval in the landmark Canadian decision of Re Application of Abitibi Co. (1982), 62 C.P.R. (2d) 81 . 


\section{Le.gal ConClusions}

In the Canadian context, the cumulative effect of the "judicial" research and the statutory "regulatory approval" exemptions has lead one author to conclude that:

[I] Canada, neither the use of a patented product or process to obtain information to be used for a regulatory approval process, nor the use, manufacture or sale of a patented product or process solcly for the purpose of experimental or testing activity prior to finalization of a commercial product for manufacture, prometion or sale is an infringing use. The Canadian exemption appears to extend to basic research. ${ }^{62}$

Such opinions (although not universally held) ${ }^{63}$ are indicative of the existence of a fairly broad exemption for bona fide experimental research and work pertaining to regulatory approvals in Canada. However, it is also clear that any activity that goes beyond the scope of experimentation or an approvals process may well constitute patent infringement. In relation to the "regulatory approval" exemption, Ferance states that "[a]ctivities in relation to the invention for any collateral purpose beyond the development and submission of information required by law would likely render the defence unavailable."

\section{EXTRA-Legai. ISSUES: Commercial aNd STRATEgic Considerations}

While it is argued that there is no legal impediment to a Canadian researcher/producer conducting research on a generic HT canola product under one of the aforementioned exemptions, there may be strategic and commercial reasons that will render this possibility unlikely. Monsanto has faced challenges related to patent expiry before.

In 1983, Monsanto was granted a U.S. Patent"ss on a glyphosate based herbicide that it eventually marketed as Roundup TM. By the year 2000 it had become the most successful agro-chemical product in history, and amassed annual global sales of US\$2.8 billion, outselling other chemicals by a ratio of $5: 1 .^{66}$ However, as Smyth notes:

The patent for Roundup was scheduled to expire in 2000. For Monsanto, this represented [a potential] influx of generic glyphosinate products on the market that would compete with and potentially diminish Roundup's large market share. Company representatives projected that market share could potentially drop from $\mathbf{7 7 \%}$ (as of 2003) to the low 60's as carly as 2005. Additionally, analysts also projected that the price for Roundup would drop to as little as S14 or S1S per gallon from its 2003 price of $\$ 23$ per gallon. As of 2003, the projected affects of competition by generic brands could have an estimated impact of $\$ 1.69$ billion in lost revenues. ${ }^{67}$

Sheldon Burshtein, "Experimental Use Exception To Patent Infringement In Canada," online: Blakes <www.blakes.ca/english/publications/brip/articlc.asp?A ID=188\&DB=blakes/Property>.

(3) See, e.g., supra notes 12,14.

(4) Ferance, supra note 11 at 35.

63 "Salts ol'N-phosphonomelhylglycinc," U.S. Palent No. 4405531 (8 March 1982, issued 20 September 1983).

th David Barbosa, "The Power of Roundup; A Weed Killer Is a Block For Monsanto To Build On" New" York Times (2 August 2001), online: New York Times <http:/query.nytimes.con/gstfullpage.html?

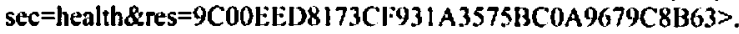


In an attempt to prevent such losses, Monsanto developed "[a] brilliant strategy of dropping its price years ahead of patent expiration and tying its use to the early growth of genetically modified crops - crops made to work in tandem with the herbicide. ${ }^{\text {, }} \mathrm{x}$

Smyth asserts that this strategy achieved two major objectives:

First, it created new value for the product through an elfective bundling strategy. Roundup was no longer vicwed primarily as a standalone product. Secondly, the new pricing strategy increased the level of adoption by producers thereby expanding Monsanto's market share. ${ }^{(0)}$

However, while the strategy certainly maintained shareholder value and propped up Monsanto's market share, it did not prevent generic glyphosate producers from infiltrating the market. As Innovest Strategic Value Advisors note: "In some cases, Monsanto has been driven out of the glyphosate market altogether, as was the case in Australia, where competition from cheap Chinese imports caused the company to close its manufacturing plant there."70

Clearly, any potential entrant into a market for generic HT canola will facc similar strategic initiatives from Monsanto attempting to ensure the continued commercial success of Roundup Ready ${ }^{\mathrm{TM}}$ Canola. One possibility is that Monsanto will reduce prices and eliminate the Technology User Fee in order to retain market share. Such an initiative could render the financial viability of a generic competitor questionable.

\section{Conclusion}

In the next decade many of the first generation of Canadian agricultural biotechnology patents will begin to expire. Monsanto's ' 830 Patent is one of the first and most signilicant. This may present an opportunity for the development of a generics manufacturing sector as there are no concrete legal obstacles to the use by potential market entrants of the two "carly working" exemptions contained under the Patent $\mathrm{ACl}^{71}$ and associated jurisprudence. At present, fiscal and commercial considerations provide more likely obstacles to the emergence of such a sector than any possible legal impediments. However, that situation may change and the uncertain nature of the scope and extent of these exemptions may once again be under scrutiny. At that stage, Parliament may have to introduce a new regulatory framework in the field of agricultural biotechnology patenting similar to the NOC regime for pharmaceutical products. Such a framework may well be necessary in order to balance the legitimate rights of patent holders with the legitimate commercial aspirations of the potential builders of a new technology sector in Canada.

Supra note 66. Roundup Ready'M Canola being the example por excellence of the clfectiveness of this product bundling stralegy.

Stupre note 8 at 34.

Innovest Strategic Value Advisors, "Monsanto \& Genctic Engineering: Risks for Investors" (January 2005), online: Innovest Group <www.innovestgroup.com/pdlis/2005-01-01_Monsanto_Genctic Engineering.pdi $>$ at 30 .

Supra note 5. 